\title{
Responses of riparian guilds to flow alterations in a Mediterranean stream
}

\author{
María Dolores Bejarano, Marta González del Tánago, Diego García de Jalón, Miguel \\ Marchamalo, Álvaro Sordo-Ward \& Joaquín Solana-Gutiérrez
}

\author{
Keywords \\ Composition; Diversity; Establishment \\ patterns; Mature forest; Pioneers; Shrubland; \\ Stream water declines \\ Nomenclature \\ López González (2001)
}

Bejarano, M.D. (corresponding author, mariadolores.bejarano@upm.es), González del Tánago, M. (marta.gtanago@upm.es) \& de Jalón, D.G. (diego.gjalon@upm.es): Grupo de investigación en Hidrobiología, Departamento de Ingeniería Forestal, Universidad Politécnica de Madrid, ES-28040, Madrid, España

Marchamalo, M. imiguel.marchamalo@upm. es): Grupo de investigación en Hidrobiología, Departamento de Ingeniería y Morfología del Terreno, Universidad Politécnica de Madrid, ES-28040, Madrid, España

Sordo-Ward, Á. (alvaro.sordo.ward@upm.es) Departamento de Ingeniería Civil: Hidráulica y Energética, Universidad Politécnica de Madrid, ES-28040, Madrid, España

Solana-Gutiérrez, J. joaquin.solana@upm. es): Grupo de investigación en Hidrobiología, Departamento de Economía y Gestión Forestal, Universidad Politécnica de Madrid, ES- 28040, Madrid, España

\begin{abstract}
Questions: Do Mediterranean riparian guilds show distinct responses to stream water declines? If observed, which are the most sensitive and resilient guilds and their most affected attributes?
\end{abstract}

Location: Tiétar river below the Rosarito dam, central-western Spain.

Methods: We identified riparian guilds based on key woody species features and species distribution within this Mediterranean river corridor, and evaluated similarity of their responses to long-term flow alteration (i.e. stream water declines since dam construction in 1959). Hierarchical cluster analysis was used to group surveyed vegetation bands according to species composition. The groups were designated as riparian guilds where each vegetation group comprising a guild: (1) contains species sharing similar features (using PCA); and (2) shares a similar environment (using DCA). Changes in several guild attributes (i.e. dominance and species composition, diversity and establishment pattems) during the regulated period were compared statistically. We used pre- and post-dam established vegetation bands identified based on old (1956) and modern (2006) aerial photographs and field measurements of woody species diameter.

Results: Responses to flow alterations varied between guilds according to ecological requirements of their species. The ability to survive water stress (i.e. 'Xeric' guilds) and drag forces caused by floods ('Torrential' guilds) allowed certain pioneer shrub-dominated guilds (e.g. Flueggea tinctoria and Salix salviifolia) to spread on newly emerged surfaces downward to the main channel after flow alterations, although new shrubland had less species diversity than pre-dam shrubland. In contrast, new hydromorphological conditions following damming limited recruitment of native late-successional tree guilds sensitive to floods (to drag forces, inundation and anoxia; i.e. 'Slow-water' and 'Flood-sensitive', respectively) and those with greater water requirements (i.e. 'Hydric') (e.g. Alnus glutinosa and Celtis australis), although species diversity increased in this mature forest through co-existence of remaining riparian species and new arrival of upland species.

Conclusions: Changes in several riparian attributes after flow alterations differed between guilds. Stream water declines after damming caused shifts in species-poor pioneer shrubland downwards to the watered channel, resulting in severe declines of mature native forest. Understanding vegetation guild responses provides information about general trends in plant populations and assemblage structures expected to occur during river development and flow regulation, increasing our capacity to detect and synthesize complex flow alteration-riparian ecosystem response relationships, and anticipate irreversible impacts. 


\section{Introduction}

The effects of altered stream flows vary among species, depending on their life-history attributes (Nilsson et al. 1991a; Jansson et al. 2000; Merritt \& Cooper 2000; Dynesius et al. 2004; Merritt et al. 2010). For example, woody species from the genera Populus, Salix, Acer and Tamarix respond differently to flow regime changes (Rood $\delta$ Mahoney 1990; Rood et al. 1999; Polzin \& Rood 2000; Lytle \& Merritt 2004; Birken \& Cooper 2006; DeWine \& Cooper 2007; Hughes et al. 2010; Merritt $\delta$ Poff 2010). Nevertheless, species-based knowledge reveals only part of the ecological consequences of flow alterations; moreover, because of the large number of plant species along rivers around the world, it is impossible to assess the impacts on all species. In addition, results from research on species are difficult to extrapolate to other geographical regions. Based on the ecological guild concept, some authors have studied the responses of groups of species (functional groups, usually referred to as guilds), assuming that species tend to associate according to similar behaviour in response to environmental conditions (Root 1967; Leonard \& Orth 1988; Simberloff \& Dayan 1991; Austen et al. 1994). This guild approach has been widely used to guide the management of fisheries (Regier et al. 1989; Welcomme et al. 2005; Kennard et al. 2007; Melcher et al. 2007), but few studies have used plant guilds to analyse riparian vegetation responses to changing hydrology and geomorphology of rivers. The identification of riparian vegetation-flow response guilds was recently proposed in Merritt et al. (2010) as a tool for determining environmental flows for riparian ecosystems. The guild approach is a synecological assessment that allows generalizations and comparisons among different fluvial systems (Severinghaus 1981).

Mediterranean rivers are among the most impounded in the world (García de Jalón 2003; Grantham et al. 2010); consequently, there is an increasing demand for scientific knowledge related to impacts of flow alterations to assure their sustainable management. In the Iberian Peninsula, the majority of riverine studies have been designed to describe and locate riparian vegetation types and assess their conservation value (Aguiar et al. 2000; Salinas et al. 2000; Garilleti et al. 2008); but few studies on the specific effects of hydrologic alterations on vegetation have been conducted (but see e.g. Aguiar \& Ferreira 2005; GarófanoGómez et al. 2009; González et al. 2010a, 2010b). The great heterogeneity of Mediterranean riparian vegetation leads to a wide range of responses to hydrologic changes. In addition, the overlapping effects of other common human disturbances (e.g. grazing, gravel mining, land occupation for agriculture, straightening and channelization) also directly or indirectly affect riparian plants (Corbacho et al. 2003), obscuring the specific consequences of flow alterations. These factors make it difficult to deepen our understanding of hydrologic alteration and vegetation responses in Mediterranean regions.

In arid region streams, riparian vegetation is particularly responsive to the hydrologic regime related to water level, flooding and hyporheic fluxes (Stromberg 1993; Ferreira \& Moreira 1999; Mitsch \& Gosselink 2000; Aguiar et al. $2001)$. Studies conducted in dry regions show that for pioneer species, a reduction of stream flow and groundwater level affects recruitment and decreases photosynthetic activity and growth because of limited water availability (Mahoney \& Rood 1992; Stromberg et al. 1996; Horton et al. 2001; Lite \& Stromberg 2005). In addition, flood magnitude reduction in semi-arid and arid environments also affects tree growth, regeneration and, ultimately, vegetation dynamics due to a lack of hydrogeomorphic disturbances that transport propagules and nutrients and remove or create new habitats for plant establishment (Stromberg et al. 1997; Corenblit et al. 2007; Dufour \& Piegay 2008). Vegetation sensitivity to stream flow changes, coupled with increasing urban and agricultural water demand, is having serious negative impacts on Mediterranean riverine ecosystems (García-Ruiz et al. 1995; Ibáñez et al. 1996; Beguería et al. 2003; Pinilla 2006; Cabezas et al. 2009). Many essential functions of riparian areas, such as stabilization of fluvial land forms (Gurnell \& Petts 2002, 2006; Corenblit et al. 2007), flood control (Hughes \& Rood 2003), hyporheic filtration and habitat, and refuge and migration corridor provision for animals (Naiman et al. 1993; Naiman \& Décamps 1997; Salinas et al. 2000) are at risk of being lost.

In this study, we investigated whether there are Mediterranean riparian guilds that show distinct responses to stream flow declines. If these phenomena were observed, our final purpose was to detect the most sensitive and resilient guilds and their most affected attributes to develop a sound scientific basis to redirect flow regime management and restoration strategies in the Mediterranean region toward especially threatened plant communities. Thus, we described the woody riparian vegetation of a $62-\mathrm{km}$ regulated reach of a Mediterranean stream in central-western Spain, identifying riparian guilds and evaluating and comparing each guild's response to flow alterations in terms of changes in composition, diversity and distribution within the riparian corridor.

\section{Methods}

\section{Study area and site locations}

The Tiétar river is a $150-\mathrm{km}$-long tributary of the Tagus river in central-western Spain and extends over $4478 \mathrm{~km}^{2}$ (Fig. 1). It originates in the Gredos Mountains at $750 \mathrm{~m}$ a. s.l., flows westward through the Rosarito reservoir, and 


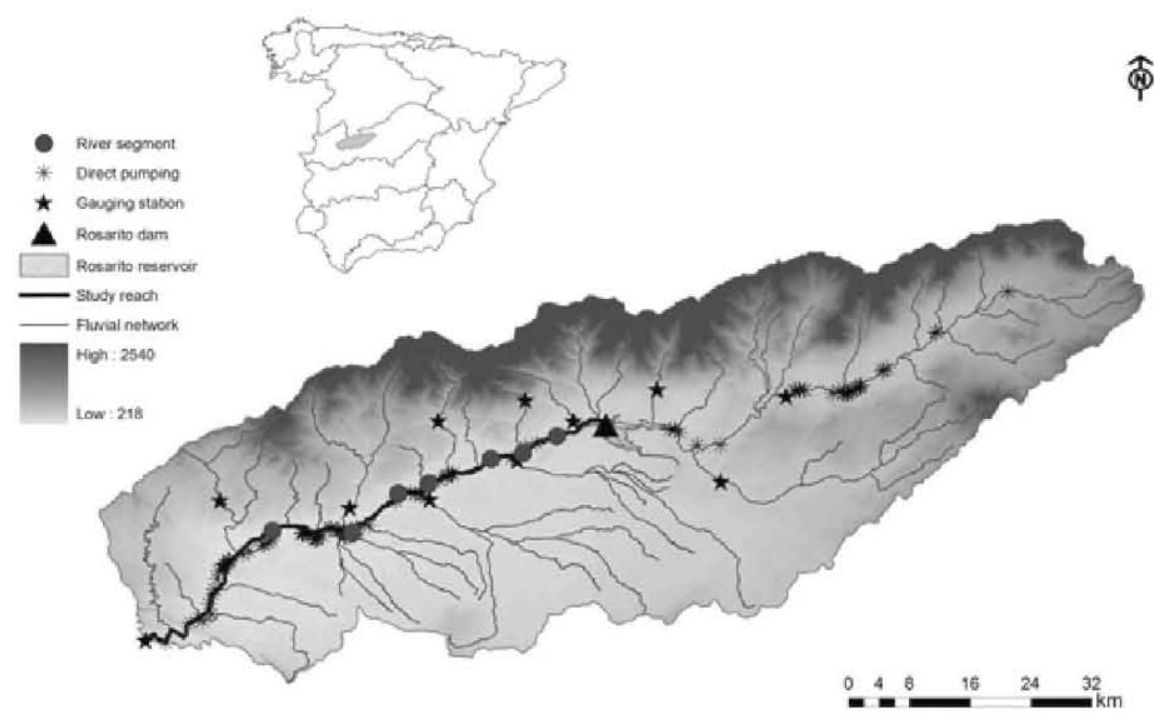

Fig. 1. The Tiétar river basin in central-western Spain. Map shows relief, river network and location of gauging stations, Rosarito reservoir, pumping stations, and surveyed river segments.

ends in the Torrejón-Tiétar reservoir between the confluence of the Tiétar and Tagus rivers. The Rosarito dam became operational in Jan 1959 and is used for irrigation (Spanish Ministry of Environment 2006). The catchment area upstream from the dam $\left(1736 \mathrm{~km}^{2}\right)$ represents $40 \%$ of the total area of the Tiétar river, and the dam has a live storage capacity of $85 \times 10^{6} \mathrm{~m}^{3}$. Water is partially diverted from the reservoir from May to Oct through two side channels to meet the water demands of the 14000 ha of crops in the lower valley. In addition, another 15000 ha of crops are supplied directly from the main channel of the study area of the river through direct pumping, mainly along its lower part (Tagus Basin Authority; http://chtajo.es; Fig. 1). The floodplain is intensively used for agriculture and is characterized by numerous settlements. In the past, extensive grazing impacted its riparian vegetation, and gravel mining affected certain river areas. Although these pressures are not active at present, they might still be relevant through their legacy effects. This study focuses on the $62-\mathrm{km}$ regulated reach of the Tiétar from below the Rosarito dam to (near) the tail of the downstream Torrejón-Tiétar reservoir (Fig. 1).

The selected river reach is a wandering to meandering channel. It presents a coarser substrate and steeper channel bed along its first few kilometers and progressively becomes a low-gradient, sand bed river downstream. The average annual rainfall exceeds $1000 \mathrm{~mm} \mathrm{yr}^{-1}$ in the mountains and occasionally occurs as snow (Spanish Meteorological Agency; http://aemet.es). In contrast, rainfall is approximately $500 \mathrm{~mm} \mathrm{yr}^{-1}$ in the lower valley. The Tiétar's stream flow is mainly sustained by surface run-off and contributions from the major tributaries. The natural total annual run-off entering the Rosarito reservoir is $766 \mathrm{hm}^{3}$ (1985-2000) (source: simulated natural flow using the Sacramento model: CEDEX-Spanish Ministry of Environment and Public Works; http://Cedex.es). Groundwater discharge from the basin which recharges the lower Tiétar valley aquifer also contributes to the flow in this part of the river (Spanish Geological Institute; http://aguas. igme.es). Consequently, the Tiétar river exhibits pluvial seasonal flow variability, with winter and spring peak flows, and naturally, it rarely dries up in summer (Fig. 2).

Seven river segments (RS1-RS7) downstream from the Rosarito dam were randomly chosen for analysis (Fig. 1), which included representative riparian forest. They were assumed to be subject to hydrologic alterations and other minor impacts that did not significantly differ among them. The homogeneity of the geomorphic and vegetation characteristics determined the length of each river segment, which was $2-\mathrm{km}$ long on average.

\section{Data collection}

Fieldwork

In the field, we surveyed each river segment. First, we established 30-m wide transects perpendicular to the river channel, from a terrace top or hillslope that contained relatively mature woody vegetation and appeared to be representative of the segment to the corresponding form on the opposite bank. The number of transects per river segment depended on the length and heterogeneity of each segment (nine transects per segment on average) and were randomly distributed. Across each transect, we identified consecutive bands of vegetation, arranged parallel to the 


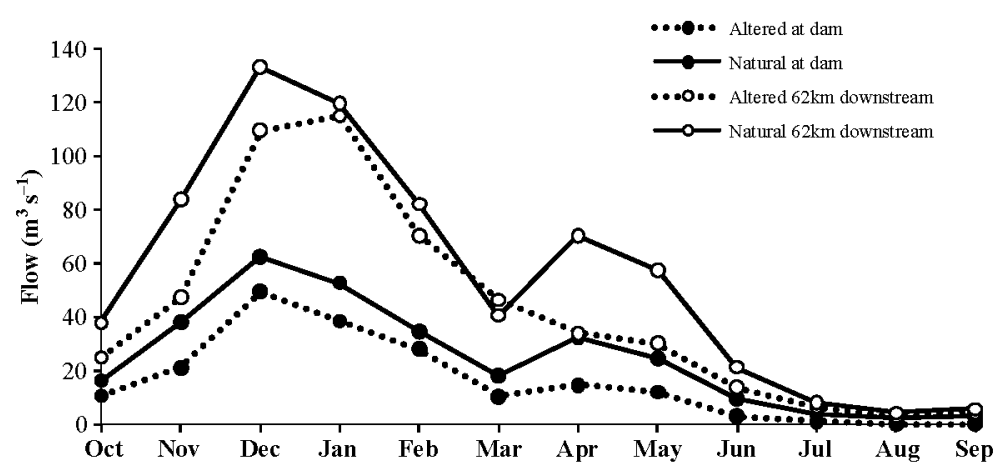

Fig. 2. Intra-annual flow fluctuations in the Tiétar river during the period 1985-2000 at the Rosarito dam site (filled dots) and 62 km downstream (unfilled dots). Black lines represent the 'natural' mean monthly flow reconstructed with models, whereas dashed lines represent the altered mean monthly flow at gauges \#3127 and \#3184.

river flow, from the left to the right bank. A band consisted of a homogeneous vegetation zone with respect to the canopy, mid-stratum and ground cover of the dominant species (according to Friedman et al. 2006; Bornette et al. 2008; Stromberg et al. 2010; Bejarano et al. 201la). Finally, bands of vegetation were characterized by determining biological and physical variables in the field. Woody species and their relative abundances were determined by dividing the number of individuals of each species by the total number of woody individuals within each band. The diameter at breast height (DBH) was measured using calipers for a representative number of individuals of the different cohorts of tree and shrub species (i.e. $50 \%$ of individuals) visually recognized in the band. The relative location of each band was measured according to the maximum, minimum and mean distance to and height above the flow level during the survey season (base flow). This was done using a Suunto level, a measuring tape and a laser distance-measuring tool. The size class and relative abundances of riparian surface substrates (first $20 \mathrm{~cm}$ of depth) were determined following the Wentworth scale and adding bedrock and peat (following Nilsson et al. 1994). The size class and its abundance were assigned based on visual inspection. Substrates were ranked in terms of water-holding capacity by weighting the value of substrate fineness by the percentage composition of the riverbank substrate, and based on nine $\Phi$ (phi) values ( $\log 2$ transformation of the size class) for peat $(\Phi-12)$, clay $(\Phi-9.0)$, silt $(\Phi-6.5)$, sand $(\Phi-2.0)$, gravel ( $\Phi 2.0)$, pebbles $(\Phi 4.5)$, cobbles $(\Phi 6.5)$, boulders $(\Phi 9.0)$ and bedrock ( $\Phi$ 12) (Wright et al. 1984). The dominant fluvial land form was noted (i.e. active and high bars, bench, floodplain and terrace; following Hupp \& Osterkamp 1996; Hupp \& Rinaldi 2009). We took qualitative notes about dominant geomorphic processes based on evidence of incision (e.g. bare, exposed roots) or aggradation (e.g. buried stems or fresh sediment on top of vegetated floodplain deposits) and the absence/presence of woody debris. Canopy cover of the bands was obtained from an average of three readings per band using a spherical densiometer. Measurements were carried out in Jul 2008. The average base flow during the surveys ranged between 3.4 and $6.2 \mathrm{~m}^{3} \mathrm{~s}^{-1}$ from the first to the last river segment, respectively.

Office work

We classified the vegetation bands surveyed in the field into pre-dam established and post-dam established. For this, we matched the DBH field data for each vegetation band with information from two series of orthophotographs taken prior to (spring and summer 1956) and after (spring 2006) the year in which the dam became operable (Jan 1959). DBH data provided age estimation of individuals, while old and modern orthophotograph comparisons allowed identification of both the riparian areas that were vegetated prior to dam operation, and those that were colonized during the regulated period. Along the selected river segments on both series of photographs, we drew polygons representing the succession phases of vegetation according to the presence and combination of specific species, dominance structure and environmental envelope (following Egger et al. 2008). We characterized the polygons as water, initial stage (i.e. bare ground), colonization stage (i.e. annual herbs, pioneer vegetation and seedlings), transition stage (i.e. reeds, grassland and shrubs or early successional woodland) and established stage (i.e. mature riparian forest). Based on these criteria, we defined: (1) 'novel' (post-dam) areas, those colonized after damming that corresponded to areas in transition and established stages on modern pictures, but were in water, initial or colonization stages in older pictures; and (2) 'relict' (pre-dam) areas, those already in transition and established stages in older pictures. The 1:30 000 older pre-dam photographs 
(provided by the CECAF: Map and Photo Air Force Center, Spanish Ministry of Defence) were previously digitized and orthorectified using the flight's camera calibration data and the corresponding 2-m pixel side digital elevation model (DEM) and ground control points from 1:10 000 scale topographic maps. The 1:25 000 modern post-dam orthophotographs were downloaded from SIGPAC (Spanish Geographic Information System for Farming Lands; http://sigpac.mapa.es). ArcGis (version 9.2) and ERDAS Imagine (version 8.5) were used for digitalization and orthorectification.

To calculate the band inundation frequencies, we used the HEC-RAS 4.1 (U.S. Army Corps of Engineers; http:// www.hec.usace.army.mil/) step-backwater hydraulic model. We predicted the water-surface elevation at discharges corresponding to the base flow, annual winter flow, bankfull discharge (2-yr return period) and 4-, 10and 25-yr return period discharges for each river segment, calculated by fitting a Gumbel distribution to data from the closest stream gauge. The channel geometry was defined for each river segment based on the cross-sections per surveyed transect. Roughness coefficients for the crosssections were estimated following Arcement \& Schneider (1989). This model was validated using the observed water-surface elevations at base flow (during the field season). A band was considered flooded when water exceeded half of the band's area.

\section{Hydrologic characterization}

We characterized the altered and natural hydrology along the study river reach using real (altered) and reconstructed ('natural') flow series from 1985 to 2000. A 15-yr period was chosen to match the available altered and natural reconstructed series. We assumed non-significant reduction of floods due to the small size of the reservoir in relation to the magnitude of floods in the area (source: Caumax software for flood simulationCEDEX-Spanish Minsitry of Environment \& Public Works 2008). The altered daily flow data were obtained from a gauging station located in the Tiétar river at the Rosarito dam (\#3127) and from a station located $62 \mathrm{~km}$ downstream before the river enters the Torrejón-Tiétar reservoir (\#3184; Fig. 1). For the altered regime calculations at each river segment, we added the Tiétar river base-flow to run-off contributions from its tributaries using information from their gauging stations (Fig. 1). For ungauged tributaries, we extrapolated the run-off values from a fitted regression to the gauged data. Direct pumping along the study river reach was also incorporated according to information provided by the Tagus Water Authority (i.e. $122 \mathrm{hm}^{3} \mathrm{yr}^{-1}$ for irrigation, mainly along the lower part of the reach, and $10 \mathrm{hm}^{3} \mathrm{yr}^{-1}$ for surrounding villages' water supplies;
Fig. 1). Because pre-dam flow series were not available, the 'natural' mean monthly flow data for the Tiétar river were obtained from reconstructed flow series provided by the Tagus Water Authority (Flores-Montoya et al. 2003; Tagus Basin Authority; http://chtajo.es). They were reconstructed using the rainfall-run-off model (Sacramento Soil Moisture Accounting model, SAC-SMA; Burnash et al. 1973), a deterministic, continuous, non-linear, semidistributed hydrologic model. For the 'natural' flow regime calculations for each selected river segment, we fitted a regression to this 'natural' reconstructed data for the larger Tiétar river. Based on this flow information, we evaluated changes in the intra-annual flow fluctuation and quantified the reduction in the average water discharge as one minus the altered/natural total annual run-off ratio.

\section{Identification of riparian guilds}

Step 1: We examined scientific literature for key attributes of surveyed riparian species (App. S1) that might condition their response to changes in flow regime or processes associated with them. The most relevant species attributes were determined with a principal components analysis (PCA) performed with Statgraphics Centurion (version XVI) on a set of 20 selected variables (Fig. 3; App. S1) describing species life history and phenology, reproductive strategy, morphology and ecology (following Merritt et al. 2010 ). Our purpose in carrying out this step was to determine whether these attributes varied by species within our surveyed species set.

Step 2: We subjected our riparian composition data set (14 woody species and percentage of abundance from the surveyed vegetation bands) to a detrended correspondence analysis (DCA) using CANOCO (version 4.5; Leps \& Smilauer 2003) to evaluate species distribution trends along the Tiétar river. Multiple regressions among DCA axes and environmental variables were used to assess how measured environmental variables influenced species spatial patterns. Categorical environmental variables were changed to dummy variables and rare species were downweighted. To quantify the relationship between the trait matrix and the community ordination, we used a canonical correlation analysis (CCA) between the PCA space and the DCA space (Statgraphics Centurion, version XVI). Step 2 was undertaken to corroborate that the species attributes determined in step 1 were reflected in the species spatial distributions within the gradients of environmental conditions in the Tiétar river corridor.

Step 3: We grouped surveyed vegetation bands according to their species composition using a hierarchical cluster analysis (see Crome 1978; Landres \& MacMahon 1980) performed with PASW Statistics (version 18) on the species abundance data from each band, so that resulting 

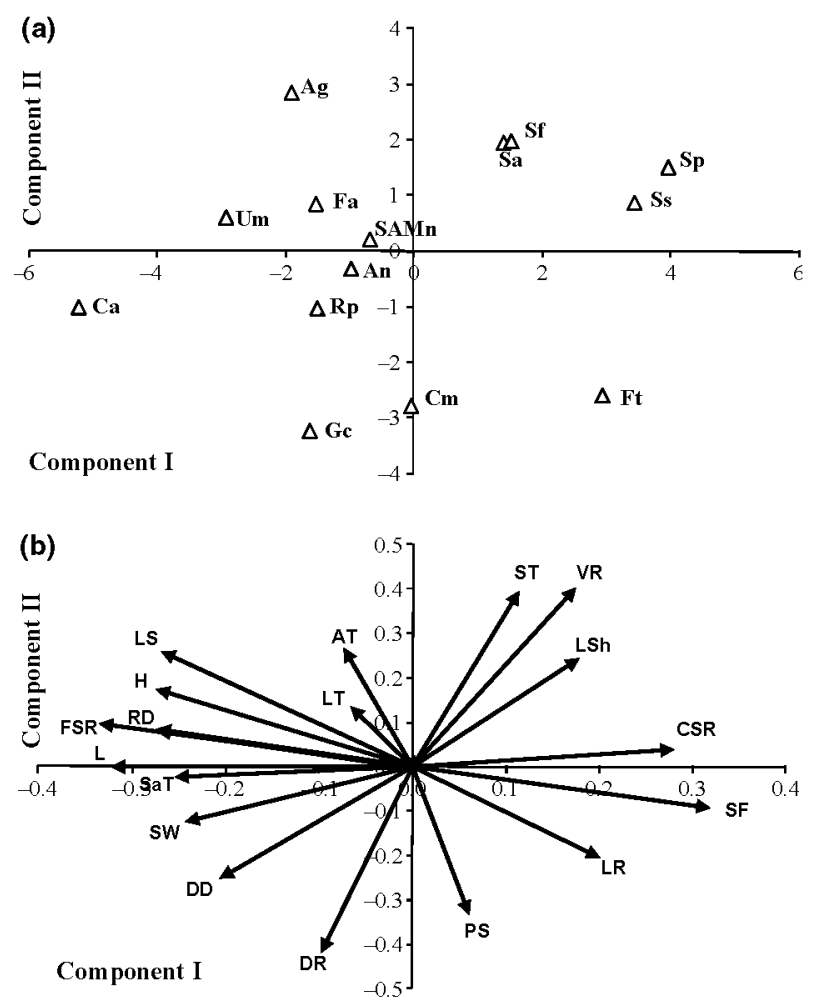

Fig. 3. PCA (principal components analysis) diagrams. The upper diagram (a) represents the dispersion of woody species in the Tiétar river according to the first two components. The lower diagram (b) represents the weight for species characteristics considered according to the first two components. Woody species are abbreviated as: Ft, Flueggea tinctoria (L.); Ss, Salix salvifolia (Brot.); Sa, Salix atrocinerea (Brot.); Sp, Salix purpurea (L.); Sf, Salix fragilis (L.); SAMn, Sambucus nigra (L.); Rp, Robinia pseudoacacia (L.); Gc, Genista cinerea (L.); Fa, Fraxinus angustifolia (Vahl); $\mathrm{Cm}$, Crataegus monogyna (Jacq.); Ca, Celtis australis (L.); An, Acer negundo (L.); Ag, Alrus glutinosa (L.); Um, Ulmus minor (Mill.). Species characteristics are abbreviated as follows (in alphabetical order): AT, anoxia tolerance; CSR, coarse substratum resistance; DD, dispersal duration; DR, drought resistance; FSR, first sexual reproduction timing; $H$, height; L, longevity; LS, leaf size; LSh, leaf shape; LT, leaf thickness; LR, light requirements; PS, presence of spines; RD, rooting depth; SaT, salt tolerance; SF, stem flexibility; ST, submergence tolerance; SW, seed weight; VR, vegetative reproduction. Note that root fastening and presence of tannins were considered in the analysis but have been omitted from the diagram due to their low weight. Further information on species characteristics used in this analysis can be found in App. S1

vegetation groups differed from each other in riparian species associations. Each group was named according to the most important flow-related attributes of its species: drought resistance (i.e. resistance to water stress: Xeric, Mesic, Hydric), drag resistance (i.e. resistance to drag forces caused by floods: 'Torrential', 'Semi-torrential' and 'Slowwater') and flood resistance (i.e. resistance to inundation and anoxia: 'Flood-tolerant' and 'Flood-sensitive'). The between-groups linkage method and the squared Euclid- ean distance (SED) were used for analysis. The threshold in the resulting dendrogram was set manually to between 3 and 5 SED to obtain a minimal number of groups that represent the heterogeneity of the river vegetation. After comparisons with PCA and DCA results, vegetation groups were designated as riparian guilds, based on the criteria that each vegetation group comprising a guild: (1) contains species that share similar attributes (deduced in step 1); and (2) shares a similar environment (deduced in step 2).

\section{Responses of riparian guilds to flow alteration}

A DCA was also used to investigate plant community composition patterns prior to and after dam construction by locating the pre-dam and post-dam surveyed vegetation bands within the ordination axis. We carried out withinguild pre-dam and post-dam comparisons to detect significant changes in guild abundance and distribution that occurred following the construction of the dam and, if present, whether this took place specifically for certain guilds. Additionally, we compared diversity changes. Shifts in the dominance of woody vegetation guilds were assessed by analysing their pre- and post-dam frequencies. Changes in guild distribution within the riparian zone were evaluated by comparing the mean establishment distance and height with respect to the base flow of each riparian guild in the pre- and post-dam bands. Woody species diversity changes were evaluated by comparing the Shannon's index (Shannon 1948) from each riparian guild in the pre- and post-dam bands. Comparisons were carried out using $t$-tests and non-parametric Kolmogorov-Smirnov and Kruskal-Wallis tests when normality, independence and homoscedasticity assumptions were not met by the data. They were performed with the PASW Statistics (version 18) software, and a 0.05 alpha level was used for all comparison tests.

\section{Results}

\section{Changes in flow regime}

Annual run-off at the dam location decreased $36.7 \%$ after dam operation began (Table 1). While natural simulated run-off during the period 1985-2000 was $766 \mathrm{hm}^{3} \mathrm{yr}^{-1}$, recorded flows during the same (regulated) period were $485 \mathrm{hm}^{3} \mathrm{yr}^{-1}$ (Table 1). At the dam site, the greatest flow declines occurred in summer (post-/pre-mean discharge ratio of 0.14 ) when water is diverted for irrigation through the two artificial side channels; whereas reservoir filling resulted in a halving of the river discharge in spring (post- $I$ pre- mean discharge ratio of 0.45 ; Fig. 2). The differences between 'natural' and altered discharges were lower during the autumn and winter seasons at the dam location (post-/pre-ratio of 0.71 ; Fig. 2). The reduction in mean 
Table 1. Data showing the 'natural' (simulated) and altered (recorded) annual run-off along the study reach of the Tiétar river during the period 19852000 , the percentage annual run-off reduction, and the change in annual run-off reduction calculated as the difference between reductions at the current and previous positions. Data are presented for several locations, corresponding to the confluence of the main tributaries, between the Rosarito dam and (near) the tail of the Torrejón-Tiétar reservoir, located $62 \mathrm{~km}$ downstream.

\begin{tabular}{|c|c|c|c|c|c|}
\hline $\begin{array}{l}\text { Location - Tributary } \\
\text { confluence }\end{array}$ & $\begin{array}{l}\text { Distance from } \\
\text { dam }(\mathrm{km})\end{array}$ & $\begin{array}{l}\text { Natural run-off } \\
\left(\mathrm{hm}^{3} \mathrm{y}^{-1}\right)\end{array}$ & $\begin{array}{l}\text { Altered run-off } \\
\left(\mathrm{hm}^{3} \mathrm{y}^{-1}\right)\end{array}$ & $\begin{array}{l}\text { Annual run-off } \\
\text { Reduction (\%) }\end{array}$ & $\begin{array}{l}\text { Change of annual } \\
\text { run-off reduction } \\
\text { relative to the } \\
\text { upstream location (\%) }\end{array}$ \\
\hline Rosarito Dam & 0 & 766.0 & 485.0 & 36.68 & 0.00 \\
\hline Alardos & 2.5 & 890.6 & 609.6 & 31.55 & -5.13 \\
\hline Minchones & 5.2 & 964.7 & 683.7 & 29.13 & -2.42 \\
\hline Alcañiza & 15.4 & 1012.8 & 727.9 & 28.13 & -1.00 \\
\hline Gualtamina & 16.2 & 1073.7 & 788.2 & 26.60 & -1.53 \\
\hline Moros & 22.5 & 1126.0 & 834.3 & 25.91 & -0.69 \\
\hline Cuartos & 25.8 & 1221.4 & 925.3 & 24.21 & -1.69 \\
\hline Sta. María & 29.8 & 1256.9 & 956.3 & 23.92 & -0.29 \\
\hline Palancoso & 39.3 & 1262.2 & 946.2 & 25.04 & 1.12 \\
\hline Casas & 41.5 & 1273.0 & 951.7 & 25.24 & 0.20 \\
\hline Fresno & 44.1 & 1461.9 & 1133.5 & 22.46 & -0.08 \\
\hline Jaraiz \& Godino & 51.4 & 1598.7 & 1250.5 & 21.78 & -0.68 \\
\hline Garguera & 60.4 & 1752.2 & 1379.5 & 21.27 & -0.51 \\
\hline
\end{tabular}

flow decreased progressively along the $62-\mathrm{km}$ study area, having a value of $21.3 \%$ at the end of the reach (Table 1). The Alardos $\left(125 \mathrm{hm}^{3} \mathrm{yr}^{-1}\right)$ and Minchones $\left(74 \mathrm{hm}^{3}\right.$ $\mathrm{yr}^{-1}$ ) streams, located a few kilometers downstream from the dam, played an important role in this progressive natural flow recovery. Far from the dam, the Jaranda stream (182 $\mathrm{hm}^{3} \mathrm{yr}^{-1}$ ) also made a large contribution. Despite the presence of tributaries, several locations along the reach did not show this recovery pattern, implying the additional effect of direct pumping. Pumping station withdrawals were estimated at $8 \%$ on average for the entire reach, but they were higher along the lower part of the river (Fig. 1). The autumn and winter post-/pre- mean discharge ratios along the lower segments remained approximately similar to values found along the upper segments, while the postdam discharge approached pre-dam values during the spring and summer (post-/pre- mean discharge ratios of 0.65 in spring and 0.87 in summer; Fig. 2). This indicates that intra-annual flow seasonality was retained after damming (Fig. 2).

\section{Description and autoecology of riparian guilds}

We surveyed 425 bands along the seven river segments. Among these, bare gravel or sand bars were excluded from our analysis, as were areas that had only seedlings because we could not be sure that they would survive in these locations. We removed either bands dominated by Populus $x$ canadensis Moench. (hybrid between P. nigra L. and P. deltoides W. Bartram ex Marshall) because they had been recently planted in the floodplains, or those dominated by upland species (e.g. Quercus spp.) to better visualize patterns among riparian species. Thus, a total of 314 vegetation bands remained for the subsequent statistical analysis (230 post-dam, 77 pre-dam and seven of unknown vegetation establishment timing). The most common tree species were Alnus glutinosa (L.) Gaertn. (black alder), Fraxinus angustifolia Vahl. (narrow-leaf ash) and Celtis australis (L.) (Mediterranean hackberry). Other native tree species were Ulmus minor Mill. (elm) and Crataegus monogyna Jacq. (hawthorn), the former being only occasionally reported. Rare exotic species were Acer negundo (L.) (box elder) and Robinia pseudoacia (L.) (false acacia). The native shrubland was dominated by Salix salviifolia Brot. (sage-leaf willow) and the Ibero-African shrubby spurge Flueggea tinctoria (L.) G.L. Webster (Spanish name tamujo). Other shrubs were Sambucus nigra (L.) (elder) and Genista cinerea (L.). Willow species such as S. atrocinerea (Brot.), S. purpurea (L.) and $S$. fragilis (L.) were rare. In general, tamujo and alder appeared along the upper river segments, while Mediterranean hackberry and elm increased downstream. Finally, ash and willows appeared in all of the studied river segments, although they were more frequent as we moved downstream (data not shown).

The PCA of the plant species attributes showed a separation between pioneer shrub species on the positive side of the first axis (variance $=38.5 \%$ ) and tree species on the negative side (Fig. 3a). This was primarily determined by the species morphology and life cycle and by phenology strategies (i.e. stem flexibility, first sexual reproduction timing and longevity; Fig. 3b). A significant separation also appeared along the second axis between tree species 
(cumulative variance of axes I and II $=60.2 \%$; Fig. $3 a$ ). Axis II mainly contained the species ecological attributes; it represented a water balance gradient (i.e. anoxia tolerance, drought resistance and submergence tolerance), with the water stress-resistant tree species on the negative side (Fig. 3). There were six statistically significant components (i.e. when eigenvalues $<1$ ), which accounted for $88.2 \%$ of the total data variance.

The DCA on the species composition data set of the Tiétar river revealed compositional differences between surveyed bands (Fig. 4a). The first two axes explained $36 \%$ of
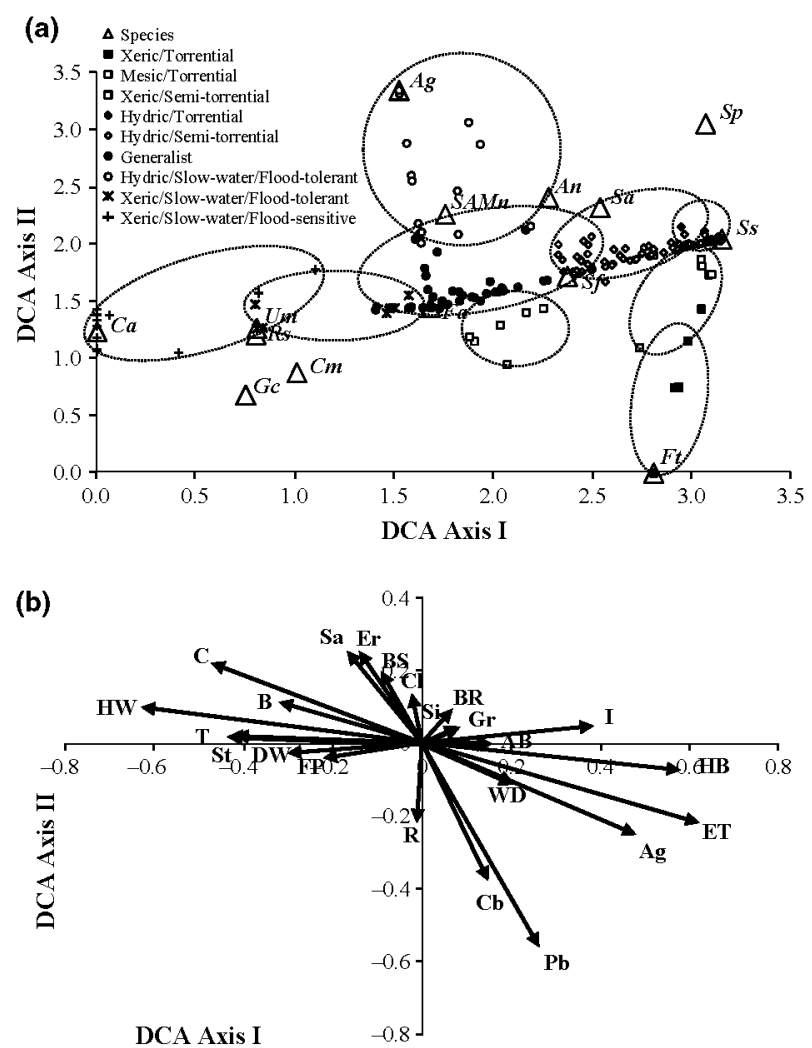

Fig. 4. DCA (detrended correspondence analysis) diagrams. The upper diagram (a) represents the species-samples biplot of the DCA of the whole data set (i.e. species composition in the surveyed vegetation bands along the Tiétar river). Triangles represent woody species, whereas the remaining symbols represent the sampled bands. Each dash large circle indicates a riparian guild assigned to the sampled bands it includes, according to the cluster analysis. The lower diagram (b) shows the retrospective projection of the environmental variables that characterized the sampled bands. Environmental variables are abbreviated as follows (in alphabetical order): $A B$, active bank; $A g$, aggradation; $B$, bench; $B R$, bedrock; BS, bank slope; C, canopy cover; Cb, cobble; $\mathrm{Cl}$, clay; DW, distance to water edge; $\mathrm{Er}$, erosion; $\mathrm{ET}$, establishment timing; $\mathrm{FP}$, floodplain; Gr, gravel; HB, high bank; HW, height above the water level; I, inundation frequency; $\mathrm{Pb}$, pebble; $\mathrm{R}$, degree of regulation; $\mathrm{Sa}$, sand; $\mathrm{Si}$, silt; St, stability; T, terrace; WD, woody debris. See legend to Fig. 3 for species abbreviations. the total variation of species data and accounted for the $60 \%$ of species-environment relations (eigenvalue axis $\mathrm{I}=0.72$; axis II $=0.55$ ). Species-environment correlations were high (Pearson's correlation coefficient $r$ axis $I=0.76$ and $r$ axis II $=0.5$ ). The most important variables that contributed significantly to inter-band floristic heterogeneity were tree and shrub establishment timing (i.e. the youngest individuals were found on the right side of the diagram) and height and land form (i.e. banks or terraces), geomorphic processes (i.e. aggradation or stability) and canopy cover along the first axis, and the size of substratum particles (i.e. sand or cobbles and pebbles) along the second axis (Fig. 4b). The first axis can be interpreted as a transverse gradient from the water to the terrace (from right to left), implying both water availability and intensity of flood disturbance lateral gradients, and a light availability gradient; whereas the second axis might be related to a gradient of substrate particle size, which is highly related to water availability for plants; water-holding capacity decreases with increasing particle size. Applying a CCA, a high correlation resulted between the two principal canonical axes from the two spaces (i.e. PCA and DCA spaces; first principal canonical axis $r=0.91 ; P<0.0001$ and second principal canonical axis $r=0.75 ; P<0.01$ ), which supports the association between the trait matrix and the community ordination.

Clustering techniques grouped the bands into nine groups according to species composition and abundances (see Table 2 for a complete list). The position of the groups along the DCA axes was overlain by band affiliation, thereby enabling visualization of the major features of the vegetation spatial patterns (Fig. 4a). DCA showed that the above-defined vegetation groups differed significantly, being distinctly arranged depending on site characteristics (Fig. 4) and according to the ecological requirements of the group associates (Table 2, Fig. 3). This result supported their designations as riparian guilds. Bands characterized by the 'Xeric/Torrential' guild (i.e. dominated by Flueggea tinctoria), the 'Mesic/Torrential' guild (i.e. co-dominated by $F$. tinctoria and Salix salviifolia) and the Xeric/Semi-torrential' guild (i.e. co-dominated by $F$. tinctoria and Fraxinus angustifolia) typically colonized the coarsest substrates and were very often found at river-disturbed sites (Fig. 4). They appeared on frequently inundated, active and aggraded banks that presented the largest deposits of woody debris. Such sites usually coincided with those that were lowest with regard to the channel. This was true for relatively pure tamujo ( $F$. tinctoria) communities, whereas site characteristics of these bands slightly differed from the aforementioned bands, with increasing abundance of willows and ash. Bands characterized by the 'Hydric/Torrential' guild (i.e. dominated by Salix spp.) shared the highly disturbed habitat with those described above, with the 
Table 2. Riparian guild assignment to sampled vegetation bands in the Tiétar river. The Table contains species abundance (\%) within the band. Riparian guilds are named according to the most important flow-related attributes of the species. Woody species are abbreviated as: Ft: Flueggea tinctoria (L.); Ss: Salix salviifolia (Brot.); Sa: Salix atrocinerea (Brot)); Sp: Salix purpurea (L.); Sf: Salix fragilis (L.); SAMn: Sambucus nigra (L.); Rp: Robinia pseudoacacia (L.); Gc: Genista cinerea (L.); Fa: Fraxinus angustifolia (Vahl); Cm: Crataegus monogyna (Jacq.); Ca: Celtis qustralis (L.); An: Acer negundo (L.); Ag: Alnus glutinosa (L.); Um: Ulmus minor (Mill.). ' $n$ ' represents the total number of sampled bands belonging to each guild.

\begin{tabular}{|c|c|c|c|c|c|c|c|c|c|c|c|c|c|c|c|}
\hline Riparian Guild & $\mathrm{Ca}$ & Um & $\mathrm{Ag}$ & $\mathrm{Fa}$ & $\mathrm{PC}$ & An & $\mathrm{Rp}$ & $\mathrm{Cm}$ & SAMn & Ss & Sa & Sf & Sp & $\mathrm{Ft}$ & GC \\
\hline Xeric/Torrential $(n=9)$ & 0 & 0 & 0 & 0.2 & 0 & 0 & 0 & 0 & 0 & 10.5 & 0 & 0 & 0 & 89.3 & 0 \\
\hline Mesic/Torrential $(n=8)$ & 0 & 0 & 1.1 & 5.8 & 1.7 & 0 & 0 & 0 & 0 & 59.7 & 0 & 0 & 0 & 31.8 & 0 \\
\hline Xeric/Semi-torrential ( $n=6)$ & 0 & 0 & 0 & 56.0 & 0 & 0 & 0 & 0.8 & 0 & 9.2 & 0 & 0 & 0 & 33.9 & 0 \\
\hline Hydric/Torrential $(n=117)$ & 0.1 & 0 & 0.2 & 0.7 & 0.3 & 0 & 0 & 0 & 0.1 & 97.1 & 0.4 & 0.02 & 0.2 & 0.02 & 0 \\
\hline Generalist ( $n=66$ ) & 3.1 & 0.9 & 0.7 & 66.3 & 0 & 0 & 0 & 1.7 & 0 & 27.0 & 0 & 0 & 0.3 & 0 & 0 \\
\hline HydridSlow-water/Flood-tolerant ( $n=15)$ & 0 & 0 & 67.2 & 24.4 & 3.2 & 0 & 0 & 0 & 0.6 & 4.7 & 0 & 0 & 0 & 0 & 0 \\
\hline Xeric/Slow-water/Flood-tolerant $(n=7)$ & 1.5 & 74.7 & 0 & 17.3 & 0.6 & 0 & 0.4 & 0 & 4 & 1.4 & 0 & 0 & 0 & 0 & 0.2 \\
\hline Xeric/Slow-water/Flood-sensitive $(n=11)$ & 84.3 & 2.0 & 0 & 1.8 & 0.7 & 0 & 0 & 1.8 & 4.6 & 0.9 & 0 & 0 & 0 & 0 & 2.5 \\
\hline
\end{tabular}

exception that they preferred finer substrates and had a higher water requirement (Fig. 4). Bands characterized by the 'Hydric/Semi-torrential' guild (i.e. co-dominated by Salix salviifolia and $F$. angustifolia) and the 'Generalist' guild (i.e. dominated by $F$. angustifolia) occupied the centre to the right side of the DCA diagram, implying flexibility for habitat conditions (Fig. 4). In general, they were located relatively high and far from the channel and usually appeared growing on stable to aggraded floodplains and high banks that were inundated more or less frequently. The more dominant the willows, the more disturbed and closer and lower to the channel were these bands. At the other extreme, bands characterized by the 'Xeric/Slow-water/ Flood-sensitive' guild (i.e. dominated by Celtis australis) and the 'Xeric/Slow-water/Flood-tolerant' guild (i.e. dominated by Ulmus minor) were generally found on the highest and less frequently flooded land forms, although the latter slightly better tolerated inundation (Fig. 4). Finally, bands characterized by the 'Hydric/Slow-water/Flood-tolerant' guild were located on fine substrate areas, coinciding with steep and eroded benches. These land forms were rarely flood-disturbed but presented good water access (Fig. 4).

\section{Shifts in guild dominance}

The tamujo shrubland, which was mainly represented by the 'Xeric and Mesic/Torrential and Semi-torrential' guilds, appeared only among the established post-dam bands. Pre-dam established bands characterized by the willow-dominated shrubland, which was represented by the 'Hydric/Torrential and Semi-torrential' guilds, were scarce; on average, these guilds established post-dam represented $85 \%$ of the willow-dominated shrubland (Fig. 5). In contrast, the relative proportion of bands characterized by the 'Hydric and Xeric/Slow-water/Flood-tolerant and
Flood-sensitive' guilds, which established during the predam period, was significantly higher than that of the postdam established bands (Fig. 5). Bands characterized by these guilds that established during the post-dam period represented $20 \%$ of the alder and hackberry forests. Among the surveyed bands characterized by the ash forest (i.e. the 'Generalist' guild), half of them were colonized after damming (Fig. 5). Finally, the relative proportion of the post-dam established riparian bands presenting the 'Xeric/Slow-water/Flood-tolerant' guild represented 71\% of the elm forest (Fig. 5).

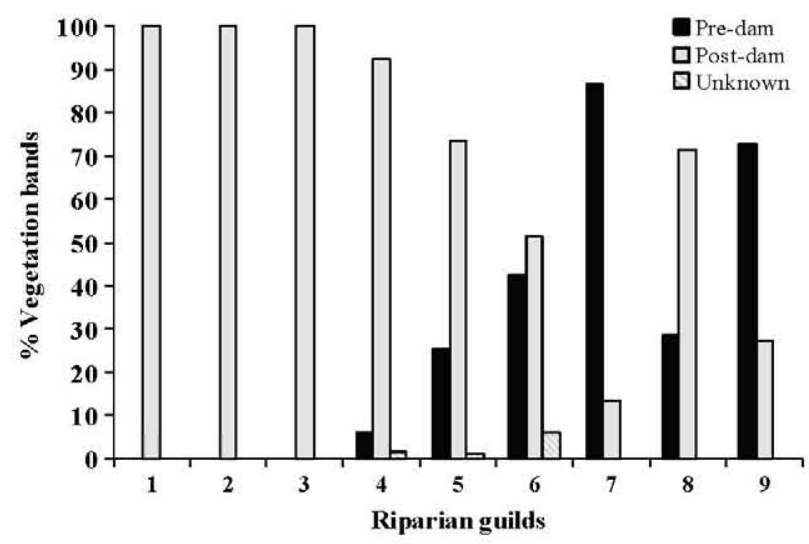

Fig. 5. Relative proportion of the riparian guilds defined for the Tietar river that established during the pre-dam and post-dam periods along the study reach. Dashed bars represent sampled bands whose vegetation establishment timing is unknown. Bars represent the percentage of sampled vegetation bands corresponding to each riparian guild and establishment timing. $\mathrm{x}$-axis contains the riparian guilds: (1) 'Xeric/ Torrential'; (2) 'Mesid/Torrential'; (3) 'Xeric/Semi-torrential'; (4) 'Hydric/ Torrential'; (5) 'Hydric/Semi-torrential'; (6) 'Generalist'; (7) 'Hydric/Slowwater/Flood-tolerant'; (8) 'Xeric/Slow-water/Flood-tolerant'; and (9) 'Xerid Slow-water/Flood-sensitive'. 
(a)
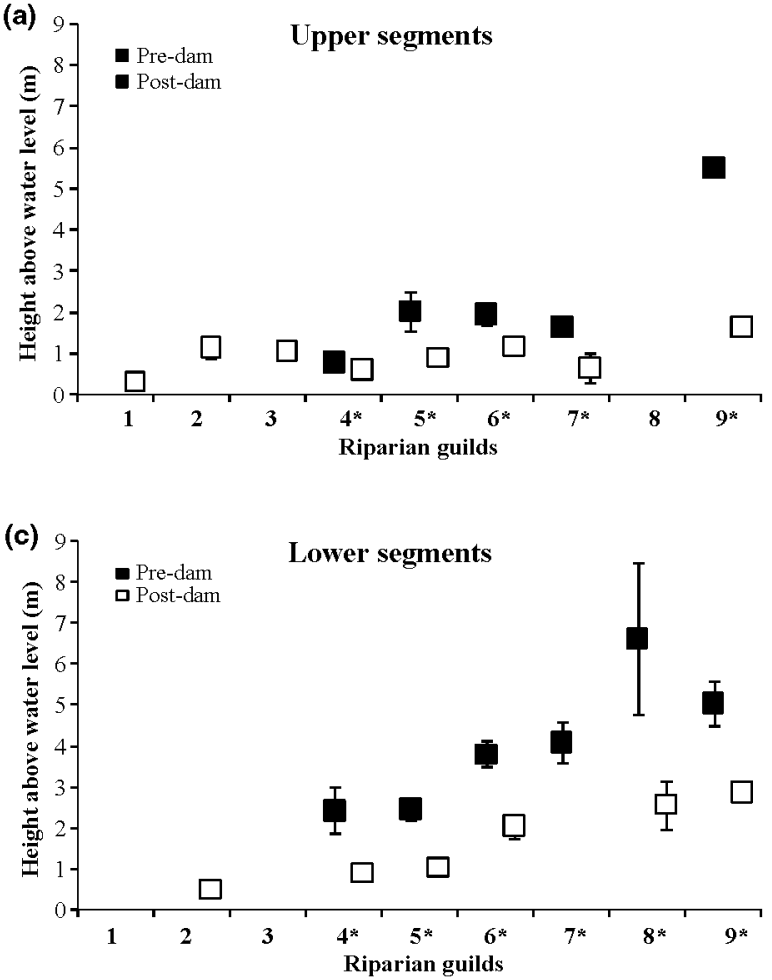

(b)

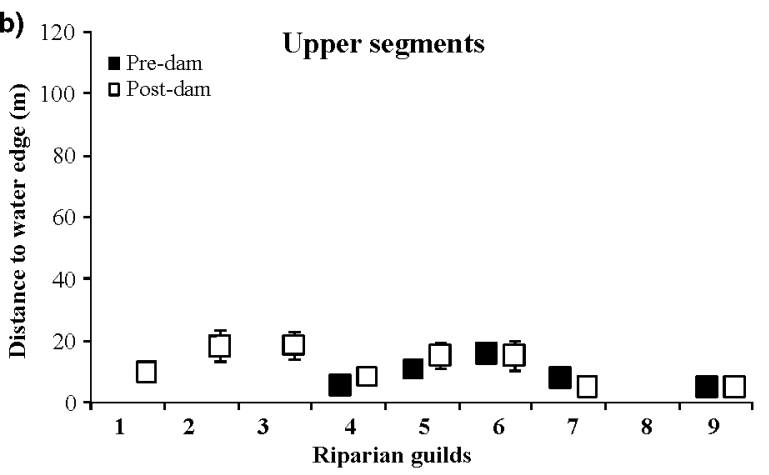

(d)

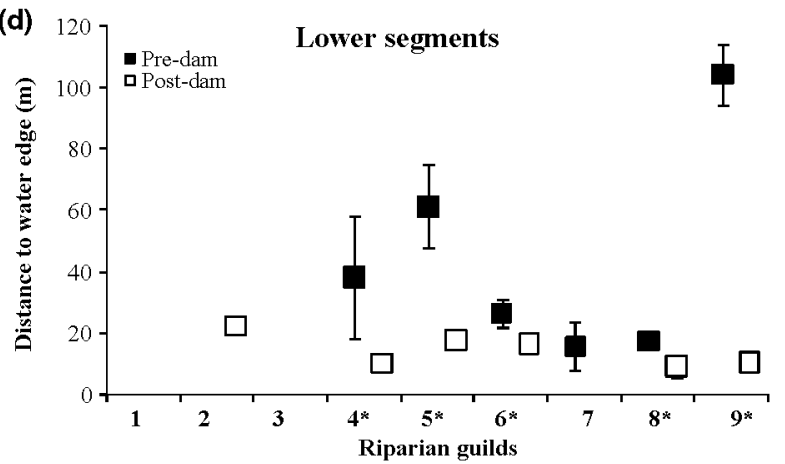

Fig. 6. Mean $\pm S E$ of the establishment height $(a, c)$ and distance $(b, d)$ relative to the water level during the sampling season for riparian guilds assigned to the surveyed bands. The Figure represents data along the upper segments (RS1-RS3; first $20 \mathrm{~km}$ downstream from the dam; (a, b) and lower segments (RS4-RS7; c, d) sampled along the Tiétar river. Pre-dam and post-dam establishment locations are represented. *indicates statistically significant pre-post differences $(P<0.05$ in $t$-test). $x$-axis contains the riparian guilds; see legend to Fig. 5 for guild names.

\section{Changes in guild establishment patterns}

Establishment positions differed significantly between riparian guilds when considering either pre-dam or postdam vegetation bands $(P<0.05$ in Kruskal-Wallis test). In general, the establishment height above the water level increased from the shrubland to the forest (Figs $4 \mathrm{~b}, 6 \mathrm{a}, \mathrm{c}$ ). 'Torrential' guilds (i.e. bands containing $F$. tinctoria and Salix spp.) appeared at the lowest surfaces, whereas the 'Slow-water' and 'Flood-sensitive' guilds (i.e. bands containing A. glutinosa, U. minor and C. australis) were distributed within the highest land forms with regard to the water level. Among the 'Slow-water' guilds, those designated as 'Xeric' (bands containing U. minor and C. australis) were located at significantly higher surfaces than the others. The 'Generalist' guild appeared on intermediate height areas. On the other hand, there were no clear patterns for the establishment distance from the water edge among the riparian guilds (Figs $4 \mathrm{~b}, 6 \mathrm{~b}, \mathrm{~d}$ ). Comparisons of individual guilds before and after dam installation showed that there was a decrease of the height and distance of establishment with regard to the water channel for all riparian guilds after the initiation of hydrologic alterations, although only height changes were statistically significant for all the guilds considered ( $P<0.05$ in $t$-test; Fig. 6$)$. When prepost comparisons were broken down by upper-lower river segments (i.e. RS1-RS3 and RS4-RS7 according to their differing geomorphic characteristics), the general trends remained, except for the vegetation establishment distance to the water along the upper segments, whose pre- and post-dam values did not differ statistically $(P>0.05$ in Kolmogorov-Smirnov test; Fig. 6a).

\section{Changes in woody species diversity}

Diversity of woody species within each surveyed band statistically differed when comparing riparian guilds $(P>0.05$ in Kruskal-Wallis test for both pre- and postdam bands; Fig. 7). Bands characterized by the 'Xeric and Hydric/Torrential' guilds presented the lowest values for the Shannon's index (0.39 on average), whereas the 'Hydric/Semi-torrential' guild showed the highest values ( 0.82 on average; Fig. 7). Within riparian guilds, pre-post comparisons of Shannon's index did not indicate any statistically significant differences $(0.05$ significance level in the $t$-test) for most of the guilds. In general, post-dam 


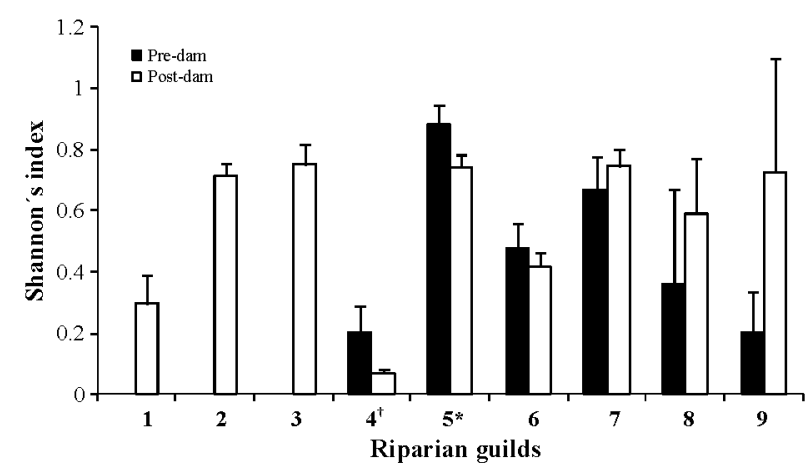

Fig. 7. Average Shannon index and standard error of pre-dam and postdam established bands corresponding to each riparian guild in the Tiétar river. *indicates statistically significant pre-post differences $(P<0.05$ in K-S test); ${ }^{\dagger}$ indicates $P$-values between 0.1 and 0.05 . $x$-axis contains the riparian guilds; see legend to Fig. 5 for guild names.

established bands characterized by the 'Torrential' and 'Semi-torrential' guilds exhibited lower diversity values than those for the pre-dam bands. The reverse was true for mature riparian forest bands characterized by the 'Slowwater' guilds, where woody species diversity was higher for the post-dam establishment (Fig. 7). On average, within-band diversity decreased $31 \%$ for pioneer shrubs and ash-dominated bands and increased $41 \%$ for bands characterized by late-successional forest.

\section{Discussion}

In this study, we identified the riparian guilds present along the Tiétar river corridor and evidenced that they responded to four main environmental gradients: flood inundation, moisture, canopy and substrate grain size. We also showed that certain species characteristics - stem flexibility, stem and root length, longevity, reproductive strategies, anoxia and submergence tolerance, drought resistance, and light requirements - control species tolerance to drag and drowning, water and light requirements and substrate preferences. Consequently, the environmental gradients existing within the Tiétar riparian corridor result in a dynamic mosaic of vegetation patches (Hupp \& Osterkamp 1996), where species with similar characteristics are clustered together and locations are determined by habitat conditions (Friedman et al. 2006; Hupp \& Rinaldi 2007).

Water withdrawals for agriculture have decreased stream discharge in the Tiétar river during the last $50 \mathrm{yr}$, significantly reducing water availability for plants. Similar to many other studies (Johnson et al. 1995; Scott et al. 1996, 1997; Merritt $\&$ ' Cooper 2000; Cooper et al. 2003; Birken \& Cooper 2006; DeWine \& Cooper 2007; Bejarano et al. 2011; Bejarano \& Sordo-Ward 2011), we found that vegetation has progressively encroached downward and inward towards the active channel in response to this change, to ensure water access. However, shifts toward the dominance and decline of particular riparian guilds along the Tiétar river during the post-dam period indicate that some guilds (i.e. pioneer shrub guilds) can take advantage of the conditions created by flow regulation, while others cannot (i.e. native late-successional guilds).

The areas colonized by vegetation correspond to newly exposed areas, which are lower and closer to the active channel. They undergo frequent fluvial disturbance events that redistribute soils and produce bank accretion. This limits the proliferation of species to those with flexible stems, rapid reproduction, resistance to burial and re-sprouting ability, and explains the proliferation of the 'Torrential' and 'Semi-torrential' guilds in the Tiétar river after damming, which are dominated by $F$. tinctoria and Salix spp. (Malanson 1993; Hughes et al. 2001, 2010; Karrenberg et al. 2002, 2003; Prada \& Arizpe 2008). In addition, the segments closest to the dam contain the coarsest substrates due to trapping of fine sediment in the reservoir and scouring processes downstream of the dam. These coarse substrates contribute to summer water stress and difficulty of rooting, creating conditions only adequate for the 'Xeric/Torrential' guilds (Gasith \& Resh 1999; Aguiar $\&$ Ferreira 2005). Finer substrates and return flows from irrigation that recharge the aquifer (Spanish Geological Institute; http://aguas.igme.es) increase as we move downstream from the dam. Thus, the combined effects of ground water contributions and the higher water-holding capacity of substrates result in less water depletion during the dry season in the lowland segments, allowing the spread of obligate phreatophytes along these segments (i.e. 'Hydric/ Torrential' guilds; Naumburg et al. 2005).

The fact that some $F$. angustifolia individuals were associated with Salix spp. individuals and shared similar locations with them (i.e. the 'Hydric/Semi-torrential' guild) reflects the ability of $F$. angustifolia to succeed in fluvial-disturbed areas, behaving as a pioneer in the Tiétar river. Additionally, mature individuals of $F$, angustifolia have also persisted on more distant and higher land forms with other nonobligate phreatophyte species, where their long roots and trunks facilitate access to water and light. Assuming that all vegetation bands were, or will be, similar in appearance at the same age (Oliver 1981; Foster 8 Tilman 2000), our findings indicate a shift in the composition and structure of late-successional riparian forests, from being initially dominated by the 'Slow-water' guilds mainly represented by A. glutinosa and C. australis in more humid or drier areas, respectively (Garilleti et al. 2008), to becoming dominated by the 'Generalist' guild dominated by F. angustifolia.

The significant and low number of post-dam bands characterized by the 'Hydric/Slow-water/Flood-tolerant' 
guild indicates a failure at some point during critical steps in the life cycle of its species under the new hydrogeomorphic conditions. High water requirements and low resistance to drag forces caused by floods of dominant species (i.e. A. glutinosa) of this guild are reported in the literature (De la Torre 1971, 2006; Costa et al. 1997; Prada \& Arizpe 2008; United States Department of Agriculture: USDA; http://usda.gov). In the Tiétar river, the survival of $A$. glutinosa seedlings on newly emerged river banks, where water availability is guaranteed, might be hampered by frequent fluvial disturbance events on these surfaces. Similar arguments may also explain the decrease of the post-dam 'Xeric/Slow-water/Flood-sensitive' guild, whose species cannot survive prolonged submergence during flooding.

Our results are not conclusive on the effect of regulation on $U$. minor forests. Surveyed bands characterized by the 'Xeric/Slow-water/Flood-tolerant' guild were very few and mortality of this species could be a consequence of Dutch elm disease (Díez \& Gil 1999). Exotic species, such as $R$. pseudoacacia and $A$. negundo, were found more frequently on newly emerged areas, associated with Salix spp. and $F$. angustifolia. However, although flow alteration seems to favour their expansion, they are still very rare, indicating that they are not competitive with other native species.

Our study revealed slightly higher woody species diversity within the post-dam established vegetation bands characterized by late-successional 'Slow-water' guilds. This pattern may be explained by the co-existence of riverine species and upland species, with the former able to survive drier and shadier conditions and the latter having accessed and successfully become established on the higher fluvial forms following stream water declines (Corenblit et al. 2007, 2008; Bejarano et al. 2011a). However, we found less woody species within the remaining riparian guilds of the Tiétar river in the vegetation bands established postdam, similar to results reported in studies downstream from dams in other areas (Nilsson et al. 1991a, 1991b; Décamps \& Tabacchi 1994; Bush \& Smith 1995; Ferreira \& Stohlgren 1999; Jansson et al. 2000; Johnson 2002; Dynesius et al. 2004).

Using a riparian guild approach increased our capacity to detect and synthesize complex flow alteration-riparian ecosystem response relationships. As such, our study suggests that riparian guilds function as 'super-species' as far as their responses to stream-flow changes are concerned. We demonstrated statistically significant changes in several riparian attributes after flow alterations, as expected according to the riparian vegetation-flow response guild theory (Merritt et al. 2010). The 'Hydric', 'Slow-water' and 'Flood-sensitive' guilds in the Tiétar river have become the guilds most threatened by regulation, as a result of the significant decrease in recruitment of the species due to the decrease in discharge and maintenance of floods after damming. In contrast, the most 'Generalist' riparian traits, together with the 'Xeric' and 'Torrential' traits, have expanded significantly during the post-dam period. We support here the use of 'indicator guilds' rather than 'indicator species' (Verner 1984), suggesting that the effect of similar stream-flow alterations to those described for the Tiétar river might similarly affect analogous guilds in other regions.

\section{Conclusions}

The guild concept can help in environmental assessment and management (Hawkins \& MacMahon 1989). As applied here, it provides a more functional evaluation of the causes and consequences of community change in response to human-caused alterations in flow regime than conventional approaches. The advantage of the riparian guild concept lies in its ability to enable the management of flow attributes for multiple species, over those prescribed to accommodate few or single species. Specifically, understanding riparian guild responses to stream-flow alterations can guide river rehabilitation and restoration projects, as well as environmental flow design. In addition, specific negative impacts of flow alterations on particular associated species can be detected, allowing restoration strategies to be focused toward especially threatened guilds.

\section{Acknowledgements}

The study was possible thanks to the María Dolores Bejarano FPU contract (AP2005-2680) for the training of university staff from the Spanish Ministry of Science and Innovation. It was also supported by funds from the POTECOL (CGL2007-66412) and MOCHCA (CGL2009-14258) projects financed by the Spanish Ministry of Science and Innovation, and from the Coordination Action VIAGUA (410AC0399) under the CYTED Program (Iberoamerican Program of Science and Technology for Development). We would like to thank Lane Butler for assistance with language and Daniel Sisí and Eufrasia Aguirre for assistance during field surveys. Finally, we are also very grateful to the Stromberg Lab Group (Arizona State University, USA) and the anonymous reviewers whose comments considerably improved the paper.

\section{References}

Aguiar, F. \& Ferreira, M.T. 2005. Human-disturbed landscapes: effects on composition and integrity of riparian woody vegetation in the Tagus river basin, Portugal. Environmental Conservation 32: 30-41. 
Aguiar, F.C., Ferreira, M.T., Moreira, I. \& Albuquerque, A. 2000. Riparian types on a Mediterranean basin. Aspects of Applied Biology 58: 1-12.

Aguiar, F.C., Ferreira, M.T. \& Moreira, I. 2001. Exotic and native vegetation establishment following channelization of a western Iberian river. Regulated Rivers: Research $\theta$ Management 17: 509-526

Arcement, G.J. \& Schneider, V. 1989. Guide for selecting Manning's roughness coefficients for natural channels and flood plains. United States Geological survey Water Supply book 2339. USGPO Washington and Dever, CO. $38 \mathrm{pp}$.

Austen, D.J., Bayel, P.B. \& Menzel, B.W. 1994. Importance of the guild concept to fisheries research and management. Fisheries 19: 12-20.

Beguería, S., López-Moreno, J.I., Lorente, A., Seeger, M. $\delta$ García- Ruiz, J.M. 2003. Assessing the effect of climate oscillations and land-use changes on streamflow in the central Spanish pyrenees. Ambio 32: 283-286.

Bejarano, M.D. \& Sordo-Ward, A. 2011. Riparian woodland encroachment following flow regulation: a comparative study of Boreal and Mediterranean streams. Knowledge and Management of Aquatic Ecosystems. In press: doi: 10.1051/ kmae/201 1059. Volume 1, article number 402.

Bejarano, M.D., Nilsson, C., González del Tánago, M. \& Marchamalo, M. 2011. Responses of riparian trees and shrubs to flow regulation along a boreal stream in northern Sweden. Freshwater Biology 56: 853-866.

Birken, A.S. \& Cooper, D.J. 2006. Processes of Tamarix invasion and floodplain development along the lower Green river, Utah. Ecological Applications 16: 1103-1120.

Bornette, G., Tabacchi, E., Hupp, C., Puijalon, S. \& Rostan, J.C. 2008. A model of plant strategies in fluvial hydrosystems. Freshwater Biology 53: 1692-1705.

Burnash, R.J.C., Ferrel, R.L. \& McGuire, R.A. 1973. A general streamflow simulation system-conceptual modeling for digital computers. Report by the Joint Federal State River Forecasting Center, Sacramento, CA, US.

Bush, D.E. \& Smith, S.D. 1995. Mechanisms associated with decline of woody species in riparian ecosystems of the southwestern U.S. Ecological Monographs 65: 347-370.

Cabezas, A., Comín, F.A., Beguería, S. \& Trabucchi, M. 2009. Hydrologic and landscape changes in the middle Ebro river (NE Spain): implications for restoration and management. Hydrology and Earth System Sciences 13: 1-12.

Castroviejo, S. (Coord.) 2005. Flora ibérica. Real Jardin Botánico. CSIC. Madrid, ES. Vols. 2, 3, 8.

CEDEX-Spanish Minsitry of Environment and Public Works 2008. Mapa de caudales máximos en la cuenca del Tajo. Centro de Estudios Hidrográficos del CEDEX. Aplicación informática de uso público, Ministerio de Fomento, Madrid, España.

Cooper, D.J., Andersen, D.C. \& Chimner, R.A. 2003. Multiple pathways for woody plant establishment on floodplains at local to regional scale. Journal of Ecology 91: 182-196.

Corbacho, C., Sánchez, J.M. \& Costillo, E. 2003. Patterns of structural complexity and human disturbance of riparian vegetation in agricultural landscapes of a Mediterranean area. Agriculture, Ecosystems and Environment 95: 495-507.

Corenblit, D., Tabacchi, E., Steiger, J. \& Gurnell, A.M. 2007. Reciprocal interactions and adjustment between fluvial landforms and vegetation dynamics in river corridors: a review of complementary approaches. Earth-Science Reviews 84: 56-86.

Corenblit, D., Gurnell, A.M., Steiger, J. \& Tabacchi, E. 2008. Reciprocal adjustments between landforms and living organisms: extended geomorphic evolutionary insights. Catena 73: 261-273.

Costa, M., Morla, C. \& Sainz, H. 1997. Los bosques Ibéricos. Una interpretación geobotánica. Editorial Planeta, Barcelona, ES.

Crome, F.H.J. 1978. Foraging ecology of an assemblage of birds in lowland rainforest in northern Queensland. Australian Journal of Ecology 3: 195-212.

De la Torre, J. 1971. Árboles y arbustos de la España Peninsular. Escuela Técnica Superior de Ingenieros de Montes, Madrid, ES. 512 pp.

De la Torre, J. 2006. Flora mayor. DG Biodiversidad, Madrid, ES. $1756 \mathrm{pp}$.

Décamps, H. \& Tabacchi, E. 1994. Species richness in vegetation along river margins. In Aquatic ecology: scale, pattern and process. Giller, P.S., Hildrew, A.G. \& Raffaelli, D.G. (eds.) pp. 1-20. Blackwell Scientific, Oxford, UK.

DeWine, J.M. \& Cooper, D.J. 2007. Effects of river regulation on riparian box elder (Acer negundo) forests in canyons of the upper Colorado river basin, USA. Wetlands 27: 278-289.

Díez, J. \& Gil, L. 1999. Effects of Ophiostoma ulmi and Ophiostoma novo-ulmi culture filtrates on elm culture from genotypes with different susceptibility to Dutch Elm Disease. European Journal for Plant Pathology 28: 399-407.

Dufour, S. \& Piegay, H. 2008. Geomorphological controls of Fraxinus excelsior growth and regeneration in floodplain forests. Ecology 89: 205-215.

Dynesius, M., Jansson, R., Johansson, M.E. \& Nilsson, C. 2004. Intercontinental similarities in riparian-plant diversity and sensitivity to river regulation. Ecological Applications 14: 173-191.

Egger, C., Exner, A. \& Jorde, K. 2008. Modelling and evaluating changes of morphology and vegetation due to dam operation. Technical study for Korea Institute of Construction Technology, Korea, $196 \mathrm{pp}$.

Ferreira, M.T. \& Moreira, I.S. 1999. River plants from an Iberian basin and environmental factors influencing their distribution. Hydrobiologia 415: 101-107.

Ferreira, L.V. \& Stohlgren, T.J. 1999. Effects of river level fluctuation on plant species richness, diversity, and distribution in a floodplain forest in central Amazonia. Oecologia 120: 582-587.

Flores-Montoya, F., Garrote, L. \& Martin-Carrasco, F. 2003. The hydrologic regime of the Tagus Basin in the last 60 years. In: Varis, O., Tortajada, C., Chevallier, P., Pouyaud, B. \& Servat, E. (eds.) Proceedings of the XI World Water Congress: water resources management in the 21st century. pp. 22-31. IWRA. Madrid, ES. 
Foster, B.L. \& Tilman, D. 2000. Dynamic and static views of succession: testing the descriptive power of the chronosequence approach. Plant Ecology 146: 1-10.

Friedman, J.M., Auble, G.T., Andrews, E.D., Kittel, G., Madole, R.F., Griffin, E.R. \& Allred, T.M. 2006. Transverse and longitudinal variation in woody riparian vegetation along a montane river. Western North American Naturalist 66: 78-91.

García de Jalón, D. 2003. The spanish experience in determining minimum flow regimes in regulated streams. Canadian Water Resources Journal 28: 1-14.

García-Ruiz, J.M., Lasanta, T., Ortigosa, L., Ruizflano, P., Martí, C. \& González, C. 1995. Sediment yield under different land uses in the spanish pyrenees. Mountain Research and Development 15: 229-240.

Garilleti, R., Calleja, J.A. \& Lara, F. 2008. Sintesis ecológica y sectorización de la vegetación de ribera de la mitad sur de España. Informe CEDEX inédito. Madrid. ES. 571 pp.

Garófano-Gómez, V., Martínez-Capel, F. \& Francés, F. 2009. Distribution patterns of riparian species in relation to channel bed in two Mediterranean rivers. Proceedings of the 7th International Symposium of Ecohydraulics. Int. Association of Hydraulic Engineering and Research (IAHR) - University of Concepción (Chile). Published by ISE 2009 Organizing Committee. ISBN: 978-981-08-2100-5.9 Pp.

Gasith, A. \& Resh, V.H. 1999. Streams in Mediterranean climate regions: abiotic influences and biotic response to predictable seasonal events. Annual Review of Ecology and Systematics 30: 51-81.

González, E., Gonzálex-Sanchís, M., Cabezas, A., Comín, F.A. \& Muller, E. 2010a. Recent changes in the riparian forest of a large regulated Mediterranean river: implications for management. Environmental Management 45: 669-681.

González, E., González-Sanchís, M., Comín, F.A. \& Muller, E. 2010 b. Hydrologic thresholds for riparian forest conservation in a regulated large Mediterranean river. River Research and Applications 26: 1-10.

Grantham, T.E., Merenlender, A.M. \& Resh, V.E. 2010. Climatic influences and anthropogenic stressors: an integrated framework for streamflow management in Mediterranean-climate California, U.S.A. Freshwater Biology 55(Suppl. 1): 188-204.

Gurnell, A.M. \& Petts, G.E. 2002. Island-dominated landscapes of large floodplain rivers, a European perspective. Freshwater Biology 47: 581-600.

Gurnell, A.M. \& Petts, G.E. 2006. Trees as riparian engineers: the Tagliamento river, Italy. Earth Surface Processes and Landforms 31: 1558-1574.

Hawkins, C.P. \& MacMahon, JA. 1989. Guilds: the multiple meanings of a concept. Annual Reviews of Entomology 34: 423-451.

Horton, J.L., Kolb, T.E. \& Hart, S.C. 2001. Response of riparian trees to interannual variation in ground water depth in a semi-arid river basin. Plant, Cell and Environment 24: 293-304

Hughes, F.M.R. \& Rood, S.B. 2003. Allocation of river flows for restoration of floodplain forest ecosystems: a review of approaches and their applicability in Europe. Environmental Management 32: 12-33.

Hughes, F.M.R., Adams, W.M., Muller, E., Nilsson, C., Richards, K.S., Barsoum, N., Decamps, H., Foussadier, R., Girel, J., Guilloy, H., Hayes, A., Johansson, M., Lambs, L., Pautou, G., Peiry, J.L., Perrow, M., Vautier, F. \& Winfield, M. 2001. The importance of different scale processes for the restoration of floodplain woodlands. Regulated Rivers: Research and Management 17: 325-345.

Hughes, F.M.R., Johansson, M., Xiong, S., Carlborg, E., Hawkins, D., Svedmark, M., Hayes, A., Goodall, A., Richards, K.S. \& Nilsson, C. 2010. The influence of hydrological regimes on sex ratios and spatial segregation of the sexes in two dioecious riparian shrub species in northern Sweden. Plant Ecology 208: 77-92.

Hupp, C.R. \& Osterkamp, W.R. 1996. Riparian vegetation and fluvial geomorphic processes. Geomorphology 14: 277-295.

Hupp, C.R. \& Rinaldi, M. 2009. Riparian vegetation patterns in relation to fluvial landforms and channel evolution along selected rivers of Tuscany (central Italy). Annals of the Association of American Geographers 97: 12-30.

Ibáñez, C., Prat, N. \& Canicio, A. 1996. Changes in the hydrology and sediment transport produced by large dams on the lower Ebro river and its estuary. Regulated Rivers: Research and Management 12: 51-62.

Jansson, R., Nilsson, C., Dynesius, M. \& Andersson, E. 2000. Effects of river regulation on river-margin vegetation: a comparison of eight boreal rivers. Ecological Applications 10: 203-224.

Johnson, W.C. 2002. Riparian vegetation diversity along regulated rivers: contribution of novel and relict habitats. Freshwater Biology 47: 749-759.

Johnson, W.C., Dixon, M.D., Simons, R., Jenson, S. \& Larson, K. 1995. Mapping the response of riparian vegetation to possible flow reductions in the Snake River, Idaho. Geomorphology 13: 159-173.

Karrenberg, S., Edwards, P.J. \& Kollmann, J. 2002. The life history of Salicaceae living in the active zone of floodplains. Freshwater Biology 47: 733-748.

Karrenberg, S., Blaser, S., Kollmann, J., Speck, T. \& Edwards, P. J. 2003. Root anchorage of saplings and cuttings of woody pioneer species in a riparian environment. Functional Ecology 17: 170-177.

Kennard, M.J., Olden, J.D., Arthington, A.H., Pusey, B.J. \& Poff, N.L. 2007. Multiscale effects of flow regime and habitat and their interaction on fish assemblage structure in eastern Australia. Canadian Fisheries Aquatic Science 64: 1346-1359.

Landres, P.B. \& MacMahon, J.A. 1980. Guilds and community organization: analysis of an oak woodland avifauna in Sonora, Mexico. Auk 97: 351-365.

Leonard, P. \& Orth, D. 1988. Use of habitat guilds of fishes to determine instream flow requirements. North American Journal of Fisheries Management 8: 399-409.

Leps, J. \& Smilauer, P. 2003. Multivariate analysis of ecological data using CANOCO. Cambridge University Press, Cambridge, UK. 
Lite, S.J. \& Stromberg, J.C. 2005. Surface water and groundwater thresholds for maintaining Populus-Salix forests, San Pedro river, Arizona. Biological Conservation 125: 153-167.

López González, G.A. 2001. Los árboles y arbustos de la Peninsula Ibérica e islas Baleares. Ediciones Mundiprensa, Madrid, España, 1727 Pp.

Lytle, D.A. \& Merritt, D.M. 2004. Hydrologic regimes and riparian forests: a structured population model for cottonwood. Ecology 85: 2493-2503.

Mahoney, J.M. \& Rood, S.B. 1992. Response of a hybrid poplar to water table decline in different substrates. Forest Ecology and Management 54: 141-156.

Malanson, G.P. 1993. Riparian landscapes. Cambridge University Press, Cambridge, UK.

Melcher, A., Schmutz, S. \& Haidvogl, G. 2007. Spatially based methods to assess the ecological status of European fish assemblage types. Fisheries Management and Ecology 14: 453463.

Merritt, D.M. \& Cooper, D.J. 2000. Riparian vegetation and channel change in response to river regulation: a comparative study of regulated and unregulated streams in the Green river basin, USA. Regulated Rivers: Research and Management 16: 543-564.

Merritt, D.M. \& Poff, N.L. 2010. Shifting dominance of riparian Populus and Tamarix along gradients of flow alteration in western North American rivers. Ecological Applications 20: 135-152.

Merritt, D.M., Scott, M.L., Poff, L.N., Auble, G.T. \& Lytle, D.A. 2010. Theory, methods and tools for determining environmental flows for riparian vegetation: riparian vegetationflow response guilds. Freshwater Biology 55: 206-225.

Mitsch, W.J. \& Gosselink, J.G. 2000. The value of wetlands: importance of scale and landscape setting. Ecological Economics 35: 25-33.

Naiman, R.J. \& Décamps, H. 1997. The ecology of interfaces: riparian zones. Annual Review of Ecology and Systematics 28: 621-658.

Naiman, R.J., Décamps, H. \& Pollock, M. 1993. The role of riparian corridors in maintaining regional diversity. Ecological Applications 3: 209-212.

Naumburg, E., Mata-González, R., Hunter, R.G., Mclendon, T. \& Martín, D.W. 2005. Phreatophytic vegetation and groundwater fluctuations: a review of current research and application of ecosystem response modeling with an emphasis on Great Basin vegetation. Environmental Management 35: 726 740.

Navarro, R. \& Galvez, C. 2002. Manual para la identificación y reproducción de semillas de especies vegetales autóctonas. Junta de Andalucía. Cordoba, ES. (2 Vols.).

Nilsson, C., Ekblad, A., Gardfjell, M. \& Carlberg, B. 1991a. Longterm effects of river regulation on river margin vegetation. Journal of Applied Ecology 28: 963-987.

Nilsson, C., Gardfjell, M. \& Grelsson, G. 1991b. Importance of hydrochory in structuring plant communities along rivers. Canadian Journal of Botany 69: 2631-2633.
Nilsson, C., Ekblad, A., Dynesius, M., Backe, S., Gardfjell, M., Carlberg, B., Hellquist, S. \& Jansson, R. 1994. A comparison of species richness and traits of riparian plants between a main river channel and its tributaries. Journal of Ecology 82: 281-295.

Oliver, C.D. 1981. Stand development-its uses and methods of study. In Means, J.E. (ed.), Forests succession and stand development research in the northwest. pp. 100-112. Forest Research Lab, Oregon State University, OR, US.

Pinilla, V. 2006. The Development of Irrigated Agriculture in Twentieth-century Spain: a Case Study of the Ebro Basin. Agricultural History Review 54: 122-141.

Polzin, M.L. \& Rood, S.B. 2000. Effects of damming and flow stabilization on riparian processes and black cottonwoods along the Kootenay river. Rivers 7: 221-232.

Prada, M.A. \& Arizpe, D. 2008. Riparian tree and shrub propagation handbbook. An aid to riverine restoration in the Mediterranean region. Generalitat Valenciana, ES. pp. 202. ISBN: 978-84482-4965-6.

Regier, H.A., Welcomme, R.L., Steedman, R.J. \& Henderson, H.F. 1989. Rehabilitation of degraded river systems. Canadian Special Publication on Fisheries and Aquatic Science 106: 86-89.

Rood, S.B. \& Mahoney, J.M. 1990. Collapse of riparian poplar forests downstream from dams in western prairies: probable causes and prospects for mitigation. Environmental Management 14: 451-464.

Rood, S.B., Taboulchanas, K., Bradle, y C.E. \& Kalischuk, A.R. 1999. Influence of flow regulation on channel dynamics and riparian cottonwoods along the Bow river, Alberta. Rivers 7: 33-48.

Root, R.B. 1967. The niche exploitation pattern of the blue-gray gnatcatcher. Ecological Monographs 37: 317-350.

Ruíz de la Torre, J. 1971. Árboles y arbustos de la España peninsular. Mundi-Prensa, Madrid, ES. 512 pp.

Ruíz de la Torre, J. 2006. Flora mayor dirección general para la biodiversidad. Ministerio de Medio Ambiente. Madrid, ES. 1756 pp.

Salinas, M.J., Banca, G. \& Romero, T. 2000. Evaluating riparian vegetation in semi-arid Mediterranean watercourses in the southeastern Iberian Peninsula. Environmental Conservation 27: 24-35.

Scott, M.L., Friedman, J.M. \& Auble, G.T. 1996. Fluvial process and establishment of bottomland trees. Geomorphology 14: 327-339.

Scott, M.L., Auble, G.T. \& Friedman, J.M. 1997. Flood dependency of cottonwood establishment along the Missouri river, Montana, USA. Ecological Applications 7: 677690.

Severinghaus, W.D. 1981. Guild theory development as a mechanism for assessing environmental impact. Environmental Management 5: 187-190.

Shannon, C.E. 1948. A mathematical theory of communication. Bell System Technical Journal 27: 379-423. 
Simberloff, D. \& Dayan, T. 1991. The guild concept and the structure of ecological communities. Annual Reviews of Ecology and Systematic 22: 115-143.

Spanish Ministry of Environment. 2006. Inventario de Presas Españolas. Formato $C D$. Ministerio de Medio Ambiente, Madrid, España.

Stromberg, J.C. 1993. Fremont cottonwood-Goodding willow riparian forests: a review of their ecology, threats, and recovery potential. Journal of the Arizona-Nevada Academy of Science 27: 97-110.

Stromberg, J.C., Tiller, R. \& Richter, B. 1996. Effects of groundwater decline on riparian vegetation of semiarid regions: the San Pedro, Arizona. Ecological Applications 6: 113-131.

Stromberg, J.C., Fry, J. \& Patten, D.T. 1997. Marsh development after large floods in an alluvial, arid-land river. Wetlands 17: $292-300$

Stromberg, J.C., Lite, S.J. \& Dixon, M.D. 2010. Effects of stream flow patterns on riparian vegetation of a semiarid river: implications for a changing climate. River Research and Applications 26: 712-729.

Suszka, B, Muller, C. \& Bonnet-Mason Beat, M. 1994. Seeds of forest broadleaves from harvest to sowing. INRA. Paris, FR. $294 \mathrm{pp}$.

Vemer, J. 1984. The guild concept applied to management of bird populations. Environmental Management 8: 1-14.

Welcomme, R.L., Winemiller, K.O. \& Cowx, I.G. 2005. Fish environmental guilds as a tool for assessment of ecological condition of rivers. River Research and Applications 21: 1-20.

Wright, J.F., Moss, D., Armitage, P.D. \& Furse, M.T. 1984. A preliminary classification of running-water sites in Great Britain based on macro-invertebrate species and the prediction of community type using environmental data. Freshwater Biology 14: 221-256.

\section{Web References}

http://aemet.es. Agencia Estatal de Meteorología.

http://aguas.igme.es. Instituto Geológico y Minero de España.

http://cedex.es. Centro de Estudios Hidrográficos. http://chtajo.es. Confederación Hidrográfica del Tajo. http:/hec.usace.army.mil/software/hec-ras/hecrasdownload.html. US Army Corps of Engineers.

http://sigpac.mapa.es. Sistema de Información Geográfica de Parcelas Agrícolas.

http://usda.gov. United States Department of Agriculture.

\section{Supporting Information}

Additional supporting information may be found in the online version of this article:

Appendix S1. Metrics used to define the riparian species guilds. They were quantified based on species traits recorded in the literature (Castroviejo 2005 ${ }^{1}$; Navarro 8 Galvez 2002²; Ruíz de la Torre 1971, 2006 3. 4; Suszka et al. 1994; ${ }^{5}$ ), the authors' field observations and measured data. Some metrics were evaluated in relative terms by a ranking of each trait (between 0 and 1 ).

Please note: Wiley-Blackwell are not responsible for the content or functionality of any supporting materials supplied by the authors. Any queries (other than missing material) should be directed to the corresponding author for the article. 